\title{
Directions of Priority Industries Development as a Basis of Economy Modernization
}

\author{
O.A. Bulavko ${ }^{1}$, L.R. Tuktarova ${ }^{l}$, and E.Yu. Nikulina ${ }^{1, *}$ \\ *Corresponding author: katerina nikulina@list.ru. \\ ${ }^{1}$ Samara State University of Economics, Samara, Russia
}

\begin{abstract}
Within the framework of this study the priority areas of the development of industries are considered as transformation technologies integrally distributed with the aim of effective implementation of the new industrial policy. The analysis of the identified problems is carried out and the consequences of the introduction of effective solutions for the real sector of the economy are examined. On the basis of the assessment the authors substantiate an approach to the study of the potential advantages of the directions of development of industrial policy in accordance with social needs and social values within the framework of a changing institutional paradigm stipulated by the transition to a new economic policy.
\end{abstract}

Keywords: modernization, high technology production, investment resources, digital economy, industrial policy, economic growth.

\section{Introduction}

Currently, the economy of many countries is undergoing a transformation associated with the new industrial revolution «Industry 4.0». The concepts «transformation» and «modernization» are closely connected. Modernization is an updating of an object, bringing it in line with new requirements and standards, technical conditions and quality indicators. According to S.N. Gavrov the concept of modernization is, as a rule, viewed in several meanings [1]. We are mostly interested in the following: catching up modernization, practiced by the countries, which try to catch up with the most developed countries; modernization as a permanent process, realized through reforms and innovations and modernization as a process of social system reconstruction aiming at development acceleration. In our opinion, the issues of modernization of the economy and society as a whole are much wider, as well as the range of meanings of modernization. A retrospective analysis of the Russian economy makes it possible to single out mobilization modernization as an independent type (of the industrial economy, the territorial-production complex, the corresponding regional varieties, etc.), i.e. modernization, the main characteristic of which (while maintaining the goals) are short implementation periods, maybe with slightly lower economic efficiency, dictated by the change in external economic and political conditions. These conditions include the need to provide military (modernization of the USSR industry in the 30-s of the last century), food (food program of the 80 -s), economic security, etc.

\section{Problem Statement}

At present many Russian and foreign authors have research works on the processes of modernization, the solution of technological problems proposed for the implementation of effective industrial policy. In this regard issues related to the new economic policy are being investigated. Many authors study the concept. Currently, there are practically no studies on the regulation of the new economic policy, identification of strategic directions of the development. There are some studies of the management sphere, however, they cover only certain areas or are limited by public regulation. At the same time, technologies are developing rapidly, and the level of the development of the society, as well as the rate of the economic growth, directly depend on the nature and directions of the industrial policy development. Therefore, planning and identifying of the priority areas of the development in the field of industrial and investment policy are the key tasks of the state. The article is devoted to these aspects and actual problems.

Andreeva\& Shevchik [2]; Baranova, Shevtsova, N. A., Dmitrieva \& E.G. [3] and also Gabrielova [4] discussed the peculiarities in the trends and mechanisms of the industrial policy in Russia. These questions are also discussed in the works of C.N. Pitelis, P. Kelmendi [5] and O.N. Soboleva, T.A. Burtseva, A.A. Nabokih \& A.V.Shpengler [6]. The role of the national services sector in the building of the country's external competitiveness were assessed; the instruments and directions of industrial relations modernization are offered by E.V. Andreeva [7] and Wu Yiyun, Zhu Xiwei, Nicolaas Groenewold [8]. D.Kiselev, Y.Popov, O.Kanygina [9] and Salfetnikov D.A., Salfetnikov A. et al. [10], consider the reasons of inefficient modernization of industrial enterprises. Industrial complex are discussed in the works of N. Rogalina [11] and T. Kolmykova, A. Telizenko, V. Lukianykhin [12]. 


\section{Research Questions}

According to the authors, the problem of industrial modernization in the broad sense of the word arose in the first years of the existence of the independent Russia, as a problem of old-fashioned structure of industry inherited from the USSR. Moreover, while in the USSR, up to the beginning of perestroika, a number of manufacturing industries were on the rise, the decline in industrial production in Russia further aggravated the structural gap between the existing industry and the required industry. A number of branches of industrial production, in particular, electronic industry, machine tool building, certain types of instrumentation production disappeared; the volume of production in the military-industrial complex significantly decreased; and the remaining enterprises were surviving due to export and conversion, that, of course, can be attributed to the lack of competitiveness of the industry in conditions of Russia's entry into the world market. The authors revealed the problems of identifying priority industries as the basis for modernization and transition to a new technological structure contributing to the effective development of the industrial production, and, in general, the industrial policy.

\section{Purpose of the Study}

The motivation for choosing modernization mechanisms of the formation of a new technological structure in industrial and investment policy as the topic of the research was the multifaceted nature of the topic, covering a wide range of issues related to the transformation of the system of economic relations; the formation of coalitions as a separate mechanism for accelerating modernization processes; the transformation of risk into a specific type of resource for the development of innovative systems; the use of human capital in the interests of investment development, elements and methods of control of the information and innovative economy. Innovative and informational economic growth is characterized by making investments in information and communication technologies (ICT), which gives a multiplicative effect to the development of industrial enterprises. Industrial policy should be aimed at the implementation of interrelated elements between management bodies and business entities regarding investment and innovation activities as well as competitiveness of industrial production sectors.

The main suggestions for this study are issues related to the possibility of increasing investment activity, since investments are the key link, and investment policy is the most important component of industrial policy, including industry. The main proposals for this study are issues related to the possibility of increasing investment activity, since investments are the key link, and investment policy is the most important component of industrial policy, including industry. It is the volume of investments that determines sustainable and dynamic development of industrial production sectors and the increase in their competitiveness in the world markets. Industrial production is characterized by a relative decrease in gross output of the manufacturing industry, while maintaining stability and growth in the sectors of the fuel and energy and raw materials complex. In Russia, the development of industries of the industrial production is associated with the transformation of financial resources into investment instruments of a long-term nature, which ensures, in practice, the connection between the volume (and efficiency) of the industrial production and the level of investment. The second suggestion of the authors is the revealing of the problems associated with the increase of competitiveness, the ability to innovate and attract direct investments to the real sector of the economy. Particularly promising directions of development are technological changes that strengthen the role of innovations and investments in the economic development of the industrial production.

\section{Research Methods}

The methods of system and factor analysis, empirical, diagnostic, retrospective, predictive, stochastic and others methods are applied. The goal of the research is to analyze the identified problems and consider the consequences of implementing effective solutions for the sectors of the real economy. The scope of the research is the highlighting priority industries as the basis for modernization. The information base of the research are the articles of Russian and foreign authors, highlighting the main problems of modern industrial policy.

\section{Findings}

An important stage in the development of industries in the real sector of the economy is the possibility of forming a new technological base of economic systems based on the use of the latest achievements in computer science, nanotechnology and bio-technology. The research potential and high-tech industries create conditions for the use of competitive advantages associated with the distribution of new technologies and the modernization of the traditional sectors of the economy, also on the account of the deployment of globally oriented specialized industries.

The very concept of modernization of a particular facility has not been unambiguously defined. For example, Professor V.A. Tsvetkov [13] believes that it is possible to use various interpretations depending on the object of modernization, and, probably, he is right, and the formulation proposed by him is good. Naturally, in view of a 
significant number of modernization facilities (for example, vertically: a machine tool, a site, a workshop, an enterprise, a territorial-production complex, a region's economy, an economy and a society of a state), a single model of modernization is not possible either vertically or horizontally. As it was already mentioned, Russia needs a catching up modernization now. And the optimal start time of it has already been missed. For more than ten years, there has been a talk about the need for this modernization, and only now there are some perspectives of it. V.V. Ivanter [14] defined the tasks of the modernization of the Russian economy as the diversification of domestic production, transformed in accordance with changing external conditions on the basis of innovative orientation. Accordingly, in order to create and activate new factors of economic growth in the framework of modernization processes that meet the challenges of the long-term period, it is necessary to consider the development of the main industries from the perspective of investment and innovation orientation, i.e. to mark the main directions and instruments of industrial policy at the state and regional levels of government. It is industrial policy that contributes to the formation of a new type of sectoral structure of industry; at the stage of economic growth contributes to its development, and at the stage of stagnation or recession does not allow the realization of an avalanche-like fall in the real sector of the economy. From our point of view, industrial policy should provide a combination of all its components and interact with other types of policies macroeconomic, foreign economic, investment, innovative, regional, environmental and social policies. At present Russian industrial sectors (although formally there are no sectors after replacing All-Russian Classifier of Economy Branches with All-Russian Classifier of Types of Economic Activity) can be divided into the following categories:

basic (main) industries that provide the export of goods and services outside the region (mechanical engineering in the broad sense, as an integrated industry; metallurgy, oil refineries, wood processing enterprises, food industry enterprises, etc.);

industries of regional importance serving regional needs (production and distribution of water, gas, electricity, heat; industrial services);

industries in which the region does not specialize in the given period (import-substituting industries, sectors of possible future development of the region), but due to changes in the development of scientific and technological progress, it is quite possible to develop them, if an appropriate resource base is provided.

An important strategic task of industrial policy implementing is to overcome the structural crisis on the basis of identifying and supporting priority industries of the region (state), taking into account its existing scientific, technical, industrial and geopolitical potential.

The structural crisis of the industrial complex of a state or any region is caused by the discrepancy of its basic structural elements (the structure of commodity products, the organizational, technical and technological structure and the structure of the distribution network) with the requirements of effective industrial activity. At the same time, one should take into account the fact that the structure of the region's economy and its core, the industrial complex, formed under pre-reform conditions, is a carrier of certain qualities that enable the region to realize one or another set of functions and at the same time act as factors supporting inertial development. As we have already said, in the current economic environment, the structure of the region's economy and the regional industrial complex often contradict to the goals of its long-term comprehensive socio-economic development and with its new strategic choice. The resolution of this contradiction is the formation of a new structure of the economy by the region which makes it possible to solve a wide range of problems of social and economic development effectively. As you know, a very significant place in the regional economy system is played by the assessment of the prospects of the industries of the existing specialization of the region, as well as the justification of the direction of its effective specialization. Accordingly, a number of indicators are used for this, in particular, the localization (concentration) coefficient of the industry on the territory of the region, calculated on the basis of comparing of the sectoral structure of the region's economy with the similar structure of the country's economy as a whole, and representing of the ratio of the sector share in the region's economy to the share of this industry in the economy of the country. From such a brief review it follows that the renewal of fixed assets of the industry as a factor in increasing competitiveness requires a selective investment policy of the state.

On the basis of the above-mentioned we can distinguish the main problems of the industrial policy of Russia:

- $\quad$ the lack of a single concept and mechanism for the implementation of industrial policy built on common goals and objectives; and first of all, the absence of the Law on Industrial Policy;

insufficiency of the regulatory framework regulating the mechanism of the industrial policy; almost in every subject of the federation in one form or another there is a regional law on industrial policy, and these legislative acts are in some cases similar as twins, and the specifics of the region's potential, the level of innovative development and the existing resource base are not taken into account;

raw material export orientation of the development of the Russian industry; avoiding the raw material orientation of the development of Russia and, accordingly, changes in the structure of export and import;

uneven development of the industry in the regional context;

the undeveloped transport infrastructure of most regions, as well as interregional transport links, which obstruct the development of industrial production, because of the impossibility of entering foreign markets, as well as of accessing the resources;

- $\quad$ low level of investment in fixed assets of industrial enterprises;

- $\quad$ territorial and sectoral unevenness of state support for enterprises.

The solution to this problem should be closely related to the possibility of stimulating economic growth on the basis of modernization with the use of available resource-efficient technologies [15]. The result of the socio-economic revolution taking place in the modern world, according to some authors [16], is the construction of a post-industrial 
society, in which information technologies, computerized systems, high tech production and innovative technologies play an important role.

\section{Conclusion}

Investment is a key part of industrial policy, investment policy is an important component of industrial policy, including sectoral. The most promising areas of development are technological changes that reinforce the role of innovation and investment in the economic development of industrial production. In conclusion we can say that the diversification of the Russian economy on the basis of modernization of its technological, institutional, personnel and management base is an essential condition for the implementation of national projects and an effective factor of integration into the global economy.

\section{References}

1. S.N. Gavrov, Modernization of Russia: Post-imperial transit (MSDTU, Moscow, 2010). [in Rus.].

2. O. Andreeva, E. Shevchik, Organizational and financial mechanism of new Russian industrial policy: Systemic approach. Journal of Applied Economic Sciences, 11(3), 351-363 (2016).

3. N.M. Baranova, N.A. Shevtsova, E.G. Dmitrieva, Industrial policy as a tool of restructuring the Russian economy. In: V. Mantulenko (Ed.), Proceedings of GCPMED 2018 - International Scientific Conference "Global Challenges and Prospects of the Modern Economic Development". The European Proceedings of Social \& Behavioural Sciences EpSBS, LVII (pp. 1877-1887). London: Future Academy (2019). DOI: 10.15405/epsbs.2019.03.191.

4. H. Gabrielova, New trends in European industrial policy. Ekonomicky Casopis, 58(9), 888-908 (2010).

5. C.N. Pitelis, P. Kelmendi, European industrial policy: Perspectives, trends and a sustainability-focused new framework. In M.N. Jovanović (Ed.), International Handbook on the Economics of Integration, II, chapter 2 (pp. 21-44) (Edward Elgar Publishing, Cheltenham, 2011).

6. O.N. Soboleva, T.A. Burtseva, A.A. Nabokih, A.V. Shpengler, Factors affecting innovations development in priority industries of a region. International Review of Management and Marketing, 6(5), 91-95 (2016).

7. E.V. Andreeva, Service industries development as a priority for national post-industrial modernization. Actual Problems of Economics, 175(1), 44-51 (2016).

8. Y.Wu, X. Zhu, N. Groenewold, The determinants and effectiveness of industrial policy in China: A study based on five-year plans. China Economic Review, 53, 225-242 (2019). DOI: 10.1016/j.chieco.2018.09.010.

9. D. Kiselev, Y. Popov, O. Kanygina, Problems of ineffective modernization at industrial enterprises and ways of their solution. In S. Bratan, S. Gorbatyuk, S. Leonov and S. Roshchupkin (Eds.), Proceedings of the ICMTMTE 2017 - International Conference on Modern Trends in Manufacturing Technologies and Equipment. MATEC Web of Conferences, 129. Les Ulis: EDP Sciences (2017). DOI: 10.1051/matecconf/201712901029.

10. D.A. Salfetnikov, A.A. Salfetnikov, E.M. Kharitonov, A.A. Popov, S.V. Khoruzhaya, Stages and problems of Russian modernization and features of soviet industrial construction in the 1920s and 1930s. Terra Sebus, 9, 337353 (2017).

11. N. Rogalina, Industrialization as a national economy problem (On the issue of the initial level of soviet industrial modernization). Voprosy Ekonomiki, 2007(2), 127-140 (2007). DOI: 10.32609/0042-8736-2007-2-127-140.

12. T. Kolmykova, A. Telizenko, V. Lukianykhin, Problems of modernization and development priorities for industrial complex. Problems and Perspectives in Management, 11(4), 28-34 (2013).

13. V.A. Tsvetkov, To the problem of modernization of the Russian economy. Economy of Metropolises and Regions, 2(38), 4-14 (2011). [in Rus.].

14. V.V. Ivanter, The necessity of modernization and the speed of the economic growth. Innovations, 8(154), 6-7 (2011). [in Rus.].

15. O.A. Bulavko, Industrial and investment policy in the post-crisis modernization of Russian industry (St. Petersburg State University, Saint-Petersburg, 2013). [in Rus.].

16. E.V. Ioda, O.A. Bulavko, G.A. Khmeleva, Yu.V. Ioda, Modernization mechanisms of new technological state of things formation. Monograph (Samara Academy of State and Municipal Management, Samara, 2013). [in Rus.]. 